\title{
Peran Komunikasi Interpersonal Dalam Mewujudkan Kesehatan Mental Seseorang
}

\author{
Asriyanti Rosmalina \\ Bimbingan dan Konseling Islam, Fakultas Ushuluddin Adab dan Dakwah, Institut \\ Agama Islam Negeri Syekh Nurjati Cirebon \\ rossmalina@yahoo.com
}

\begin{abstract}
Abstrak
Komunikasi interpersonal adalah komunikasi antar seorang komunikator dengan seorang komunikan. Jenis komunikasi tersebut dianggap paling efektif untuk mengubah sikap, pendapat, atau perilaku manusia berhubung prosesnya yang dialogis. Sedangkan kesehatan mental dipandang sebagai aktivitas penyesuaian individu untuk memperoleh kondisi mental yang sehat. Sehingga peran komunikasi interpersonal diperlukan dalam mewujudkan kesehatan mental seseorang, karena melibatkan peran kedua belah pihak, baik dari komunikan maupun komunikator. Sehingga seseorang akan terpacu untuk berperan aktif mengatur alur komunikasi.
\end{abstract}

Kata Kunci: alur komunikasi, kesehatan mental, komunikan, komunikator, komunikasi interpersonal.

\section{PENDAHULUAN}

Mental yang sehat adalah suatu kondisi yang diimpikan semua orang. Bagaimana tidak, mental adalah hal terpenting dalam proses sosial di masyarakat. Mental yang sehat atau tidak akan mempengaruhi arus keterlibatan diri pada segmentasi pengaruhnya di tengah-tengah masyarakat. Orang yang memiliki mental yang sehat akan menjadi motor penggerak dalam dinamisasi perubahan yang terjadi di masyarakat, menjadi sumber inspirasi dan daya magnet akan munculnya inisiasiinisiasi yang brilian dan revolusioner. Sehingga perlu suatu peran yang bisa menghantarkan mental sesoerang menjadi mental yang sehat, tidak mengalami suatu gangguan apapun yang akan menghambat kinerja dan keterlibatan aktif seseorang di tengah-tengah masyarakat.

Komunikasi interpersonal merupakan disiplin ilmu yang dipandang mampu mewujudkan kesehatan mental seseorang, karena di dalam ruang lingkup kajiannya, komunikasi interpersonal bersifat dialogis. Sifat dialogis itu ditunjukan melalui komunikasi lisan dalam percakapan yang menampilkan arus balik yang langsung. Jadi komunikator mengetahui tanggapan komunikan pada saat itu juga, komunikator mengetahui dengan pasti apakah pesan-pesan yang dia kirimkan itu diterima atau ditolak, berdampak positif atau negatif. 
Jika tidak diterima maka komunikator akan memberi kesempatan seluasluasnya kepada kommunikasi untuk bertanya. Jadi, komunikasi interpersonal berpengaruh terhadap kesehatan mental seseorang, karena pada prosesnya komunikasi interpersonal bersifat dialogis, yang mana komunikan akan berperan untuk menyeimbangi peran komunikator, agar tercipta pola komunikasi yang baik.

\section{PEMBAHASAN}

\section{A.Pengertian Komunikasi Interpersonal}

Effendy (1986) mengemukakan bahwa, pada hakikatnya komunikasi antarpribadi adalah komunikasi antar seorang komunikator dengan seorang komunikan. Jenis komunikasi tersebut dianggap paling efektif untuk mengubah sikap, pendapat, atau perilaku manusia berhubung prosesnya yang dialogis. Sifat dialogis itu ditunjukan melalui komunikasi lisan dalam percakapan yang menampilkan arus balik yang langsung. Jadi komunikator mengetahui tanggapan komunikan pada saat itu juga, komunikator mengetahui dengan pasti apakah pesan-pesan yang dia kirimkan itu diterima atau ditolak, berdampak positif atau negatif. Jika tidak diterima maka komunikator akan memberi kesempatan seluasluasnya kepada kommunikasi untuk bertanya (Manara 2012).

Sementara itu, Dean C. Barnlund (1968) mengemukakan, komunikasi antarpribadi selalu dihubungkan dengan pertemuan antar dua, tiga atau mungkin empat orang yang terjadi secara spontan dan tidak berstruktur. Rogers dalam Depari (1988) mengemukakan pula, komunikasi antar pribadi merupakan komunikasi dari mulut ke mulut yang terjadi dalam interaksi tatap muka antara beberapa pribadi. Tan (1981) mengemukakan bahwa komunikasi antarpribadi adalah komunikasi tatap muka antara dua atau lebih orang (Mulyana 2008).

\section{Karakteristik Komunikasi Interpersonal}

Berdasarkan pengertian yang telah dijelaskan, komunikasi interpersonal dapat disimpulkan beberapa ciri khas yang membedakan antara komunikasi massa dan komunikasi kelompok. Menurut Barnlund (1968) ada beberapa ciri komunikasi antarpribadi, yaitu komunikasi antarpribadi selalu:

a. Terjadi secara spontan.

b. Tidak mempunyai struktur yang teratur atau diatur.

c. Terjadi secara kebetulan.

d. Tidak mengejar tujuan yang telah direncanakan terlebih dahulu.

e. Dilakukan oleh orang-orang yang identitas keanggotaan yang kadangkadang kurang jelas.

f. Bisa terjadi sambil lalu.

Reardon (1987) mengemukakan juga bahwa komunikasi antarpribadi mempunyai enam ciri, yaitu komunikasi antarpribadi :

a. Dilaksanakan atas dorongan berbagai faktor.

b. Mengakibatkan dampak yang disengaja dan yang tidak disengaja;

c. Kerap kali berbalas-balasan. 
d. Mengisyaratkan hubungan antarpribadi antara paling sedikit dua orang.

e. Berlangsung dalam suasana bebas, bervariasi dan berpengaruh.

f. Menggunakan pelbagai lambang yang bermakna.

Berdasarkan pelbagai pendapat tersebut di atas maka kita dapat merumuskan beberapa ciri komunikasi antarpribadi, yaitu ciri:

a. Spontanitas, terjadi sambil lalu dengan media utama adalah tatap muka.

b. Tidak mempunyai tujuan yang ditetapkan terlebih dahulu.

c. Terjadi secara kebetulan diantara peserta yang identitasnya kurang jelas.

d. Mengakibatkan dampak yang disengaja dan tidak disengaja.

e. Kerap kali berbalas-balasan.

f. Mempersyaratkan hubungan paling sedikit dua orang dengan hubungan yang bebas dan bervariasi, ada keterpengaruhan.

g. Harus membuahkan hasil.

h. Menggunakan lambang-lambang yang bermakna (Dr. Alo Liliweri 1997).

\section{Tahapan Hubungan Komunikasi Interpersonal}

Hubungan Interpersonal adalah dimana ketika kita berkomunikasi, kita bukan sekadar menyampaikan isi pesan, tetapi juga menentukan kadar hubungan interpersonalnya. Jadi, ketika kita berkomunikasi kita tidak hanya menentukan content melainkan juga menentukan relationship (Rakhmat 2007).

Berikut beberapa teori yang menjelaskan tentang hubungan interpersonal, yaitu:

a. Model Pertukaran Sosial. Model ini memandang bahwa hubungan interpersonal sebagai transaksi dagang (Thibault dan Kelley).

b. Model Peranan. Model ini menganggap bahwa hubungan interpersonal sebagai panggung sandiwara dimana yang dapat memerankan perannya dengan baik maka ia-lah yang dapat mengembangkan hubungan interpersonalnya dengan baik pula.

c. Model Interaksional. Model ini menganggap bahwa hubungan interpersonal sebagai sister. Terdiri dari banyak sistem yang saling berhubungan dan cenderung memelihara dan mempertahankan sebagai suatu kesatuan.

Adapun tahap-tahap hubungan interpersonal (Rakhmat 2007), adalah:

a. Pembentukan (Tahap Perkenalan). Menurut Charles R. Berger, informasi pada tahap perkenalan dapat dikelompokan pada tujuh kategori, yakni: Informasi demografis, sikap dan pendapat, rencana yang akan datang, kepribadian, perilaku pada masa depan, orang lain, serta hobi/minat.

b. Peneguhan Hubungan. Hubungan interpersonal selalu berubah-ubah, oleh karena itu untuk memelihara hubungan tersebut dibutuhkan beberapa faktor, yakni: Keakraban, kontrol, respon yang tepat, dan nada emosional yang tepat. 
c. Pemutusan Hubungan. Menurut R.D. Nye dalam bukunya yang berjudul Conflict Among Humans, ada lima sumber konflik yang dapat menyebabkan putusnya suatu hubungan, yakni: Kompetisi, dominasi, kegagalan, provokasi, dan perbedaan nilai.

Sedangkan, terdapat enam tahap dalam menjalin hubungan interpersonal menurut Joseph A. de Vito (Mohamad 2008), diantaranya:

a. Kontak. Di tahap ini, kontak sifatnya umum dan tidak personal.

b. Keterlibatan. Keterlibatan yang kondusif akan mendorong individu untuk menjalin hubungan secara lebih intens.

c. Keakraban. Keakraban awalnya terbentuk saat dua individu atau lebih memiliki komitmen.

d. Kemunduran. Karakter hubungan pada tahap ini adalah melemahnya keterikatan sosial antarindividu.

e. Pembenahan. Satu atau lebih individu membuat jeda hubungan antar mereka di waktu terjadi kemunduran hubungan

f. Pengakhiran. Biasanya diawali dengan pemisahan antar individu, yang dilanjutkan dengan pemisahan diri dengan lingkungan sosial yang lebih besar.

\section{Jenis Hubungan Interpersonal}

Menurut Rakhmat 2007), ada beberapa jenis hubungan interpersonal, diantaranya:

a. Berdasarkan jumlah individu yang terlibat: 1) Diad (hubungan antar dua individu; 2) Triad (hubungan antar tiga individu).

b. Berdasarkan Tujuan yang ingin dicapai: 1) Hubungan tugas; 2) Hubungan sosial.

c. Berdasarkan jangka waktu: 1) Hubungan jangka pendek; 2) Hubungan jangka panjang.

d. Berdasarkan tingkat kedalaman/keintiman: 1) Hubungan biasa; 2) Hubungan akrab/intim.

\section{Faktor yang Mempengaruhi Hubungan Interpersonal}

Hal yang mempengaruhi hubungan interpersonal (Rakhmat 2007), yaitu:
a. Komunikasi efektif
b. Kesamaan karakter personal
c. Ekspresi wajah
d. Daya tarik
e. Kepribadian
f. Ganjaran
g. Stereotyping
h. Kompetensi

\section{Teori-teori Ketertarikan Komunikasi Interpersonal}

Ada beberapa teori yang bisa menjelaskan mengapa manusia bisa saling tertarik satu dengan yang lain, yaitu:

a. Teori kognitif. Teori kognitif menekankan proses berpikir sebagai dasar yang menentukan tingkah laku.

b. Teori penguatan. Teori penguatan memiliki dasar cukup sederhana, yaitu bahwa orang ditarik oleh hadiah dan ditolak oleh hukuman. 
c. Teori Interaksionis. Teori ini dikembangkan di dalam situasi alamiah dimana suatu keputusan selalu dihubungkan kepada situasi soial dimana seseorang menemukan dirinya.

d. Teori Perubahan Sosial. Gagasan bahwa perasaan orang tentang suatu hubungan tergantung pada persepsinya mengenai hasil positif (rewards) dan ongkos (costs) hubungan, jenis hubungan yang mereka jalani dan kesempatan mereka untuk memiliki hubungan yang lebih baik dengan orang lain.

e. Teori Penyeimbang. Gagasan bahwa orang akan bahagia dengan hubungan yang dijalinnya bila pengalaman rewards dan costs dan kontribusi antara dua belah pihak diperkirakan seimbang.

Bringham dalam Dayakisni: 2008 mendefinisikan daya tarik interpersonal sebagai satu kecenderungan untuk menilai seseorang atau suatu kelompok secara positif, dan berperilaku secara positif, sesuai apa adanya. Faktor yang mempengaruhi hal-hal tersebut adalah:

a. Kesamaan (Similarity). Sikap, nilai, minat, latar belakang dan kepribadian yang sama, bisa menyebabkan individu tertarik dengan orang lain. Dalam membangun satu hubungan kesamaan bisa menjadi dasar untuk membangun hubungan yang lebih baik dan positif.

b. Kedekatan (Proximity). Kedekatan merujuk pada bentuk teritorial. Dekatnya jarak individu dengan orang lain, mengakibatkan bentuk hubungan menjadi lebih baik.

c. Daya tarik fisik. Ketertarikan seseorang seringkali dimulai dengan daya tarik fisiknya terlebih dahulu. Karena faktor ini merupakan faktor yang muncul pada awal proses ketertarikan interpersonal yang sangat sulit untuk direkayasa

Saat manusia menjalin KAP dengan individu lain, maka saat itulah relationship muncul. Relationship dalam KAP diklasifikasikan menjadi beberapa jenis oleh para ahli, namun secara umum, ada 4 jenis relationship dalam KAP, yaitu 1) friendship; 2) romantic/love; 3) family; dan 4) workplace.

a. Friendship (Pertemanan)

1) Karakteristik pertemanan.

Beberapa karakteristik pertemanan, yakni: a) kesediaan berinvestasi (waktu, usaha, pemikiran, perasaan); b) kedekatan emosional (dialog \& aktivitas); c) kesediaan menerima; d) kepercayaan; dan e) dukungan.

2) Perkembangan Hubungan Pertemanan, meliputi : a) role-limited interaction (Perkenalan awal); b) friendly relations (Mencari kesamaan ); c) moving toward friendship (Mulai melakukan hal tidak reguler bersama); d) nascent friendship (Embrio pertemanan yang tetap); e) 
stabilized friendship (Tidak perlu konfirmasi lagi, sudah yakin akan saling setuju); dan f) waning friendship (Berhenti berteman).

3) Guidelines for Communication Between Friends, meliputi: a) saling memahami; b) saling jujur; c) jadikan perbedaan sebagai kelebihan; dan d) jangan terlalu fokus pada hal kecil.

\section{b. Romantic/Love Relation}

Romantic relationships merupakan hubungan antara individu yang merasa bahwa mereka akan bertahan dan menjadi bagian satu sama lain seterusnya.

\section{1) Dimensi Romantic Relationship}

Dimensi romantic relationship juga dikenal sebagai Triangle of Love: a) Passion/perasaan positif \& hasrat intensif. (seksual, emosional, intelektual, spiritual); b) Commitment (keinginan untuk tetap terlibat dalam hubungan); dan c) Intimacy (perasaan kedekatan, keterhubungan, kelembutan).

2) Perkembangan Romantic Relationship

Perkembangan romantic relationship, yakni:

a) Growth, meliputi: (1) individuality (memikirkan kebutuhan diri sendiri); (2) invitational communication (ada sinyal ketertarikan untuk berinteraksi \& merespon sinyal tersebut); (3) explorational communication (mulai bertukar informasi); (4) intensifying communication (menghabiskan waktu bersama); (5) revising communication (menganalisis hubungan menjadi lebih realistis); dan (6) commitment (keputusan untuk tetap berada dalam hubungan).

b) Navigation, merupakan proses berkelanjutan mengenai komitmen dan kebersamaan di tengah-tengah kebahagiaan dan kesedihan yang kadang muncul dalam kehidupan. Meliputi: (1) relational culture (berhubungan dengan aturan mengenai hubungan, saling memahami, pola berperilaku dan saling menginterpretasi antar pasangan); dan (2) placemaking (proses menciptakan situasi nyaman yang merefleksikan nilai-nilai, pengalaman, dan gaya dari pasangan tersebut).

c) Deterioration, meliputi: (1) intrapsychic processes (salah satu pasangan/ keduanya mulai merasa tidak puas dengan hubungan yang ada, fokus pada kekurangan \& permasalahan yang ada); (2) dyadic processes (hilangnya pola \& aturan yang ada dalam hubungan); (3) social support (pasangan mulai mencari dukungan dari teman atau keluarga); (4) grave-dressing processes (menganggap hubungan sudah berakhir, atau bisa diisi dengan refleksi); dan (5) resurrection processes (bangkit lagi dan melupakan masalah).

\section{Atraksi Komunikasi Interpersonal}

Atraksi interpersonal adalah kesukaan pada orang lain, sikap positif dan daya tarik seseorang. Makin tertarik kita dengan orang lain maka semakin besar 
kecenderungan kita untuk berkomunikasi dengan orang lain. Atraksi timbul oleh adanya faktor-faktor baik yang bersifat personal maupun situasional.

a. Faktor Personal

1) Kesamaan karakteristik personal

Kesamaan karakteristik personal ditandai dengan kesamaan dalam nilainilai, sikap, keyakinan, tingkat/status sosisal ekonomi, agama, ideologi, dan lain-lain. Mereka yang memiliki kesamaan dalam hal-hal tadi, cenderung menyukai satu sama lain.

2) Tekanan emosional (stres)

Orang yang berada di bawah tekanan emosional, stres, bingung, cemas dan lain-lain akan menginginkan kehadiran orang lain untuk membantunya, sehingga kecenderungan untuk menyukai orang lain semakin besar.

3) Harga diri yang rendah

Orang yang rendah diri cenderung mudah untuk menyuaki orang lain. Orang yang merasa penampilan dirinya kurang menarik akan mudah menerima persahabatan dari orang lain.

4) Isolasi sosial

Sebagai makhluk sosial, manusia mungkin tahan untuk hidup terasing selama beberapa waktu, namun tidak untuk waktu yang lama. Beberapa penelitian menunjukkan bahwa tingkat isolasi sosial sangat besar pengaruhnya terhadap kesukaan kita pada orang lain.

b. Faktor-faktor Situasional

1) Daya tarik fisik (physical attractiveness)

Beberapa penelitian mengungkapkan bahwa daya tarik fisik seseorang sering menjadi penyebab utama atraksi interpersonal. Mereka yang berpenampilan cantik menarik biasanya lebih mudah mendapat perhatian dan simpati orang.

2) Ganjaran (reward)

Pada umumnya seseorang akan menyukai orang yang memberikan ganjaran pada dirinya. Ganjaran bisa berupa bantuan, dorongan moral, pujian atau hal-hal yang meningkatkan harga diri kita.

3) Familiarity

Seseorang atau hal-hal yang sudah kita kenal dan akrab dengan kita biasanya lebih disukai daripada hal-hal atau orang yang masih asing bagi kita. Contohnya adalah dengan penerapan teknik repetisi dalam iklan agar kita semakin akrab dengan produk yang diiklankan sehingga akhirnya menyukai produk tersebut.

4) Kedekatan (proximity) atau closeness.

Hubungan kita dengan orang lain tergantung seberapa dekat kita dengan orang tersebut. Sebagai contoh, sejumlah kasus menunjukkan bahwa orang lebih menyukai orang lain berdekatan tempat tinggal dengannya. 


\section{5) Kemampuan (competence)}

Terdapat kecenderungan bahwa seseorang lebih menyukai orang lain yang memiliki kemampuan lebih tinggi atau lebih berhasil dalam kehidupannya daripada dirinya.

\section{Perbedaan antara Komunikasi Interpersonal dengan Komunikasi Intrapersonal}

Ada perbedaan mendasar dari kata yang mengawali kata personal yaitu intra dan inter. Mari kita sama-sama telaah perbedaannya. Terlebih dahulu kita definisikan kata personal. Personal biasa kita fahami sebagai pengertian lain dari kata individu, pribadi atau diri sendiri.

Intra menurut bahasa artinya di dalam. Singkat kata komunikasi intrapersonal adalah komunikasi yang terjadi di dalam diri seseorang dengan dirinya pribadi. Hal ini dimaksudkan seseorang untuk mengenal kepribadian dirinya secara mendalam dan juga berfungsi untuk meningkatkan kesadaran dalam dirinya. Ketika seseorang melakukan komunikasi intrapersonal, pada saat itu dia sedang terlibat aktif dalam memproses balik (feedback) informasiinformasi yang ada dirinya. Contoh dari komunikasi intrapersonal adalah berimajinasi, berkhayal, berdoa dan bersyukur.

Sedangkan inter menurut bahasa memiliki arti di luar. Jadi dapat dijelaskan komunikasi intrapersonal adalah komunikasi yang terjadi antara seseorang dengan luar dirinya. Dengan kata lain, komunikasi yang terjadi antara satu orang dengan orang yang lain. Jadi untuk mendapatkan feedback, harus ada pihak lain (orang lain) yang terlibat aktif dalam komunikasi ini. Contoh dari komunikasi interpersonal adalah wawancara, pidato, mengorol dan mengajar.

Ada beberapa perbedaan antara komunikasi intrapersonal dengan interpersonal. Salah satunya yaitu jika seseorang berkomunikasi secara tatap muka (interpersonal), ia akan langsung menerima feedback dari komunikannya saat proses interaksi berlangsung. Sedangkan, dalam komunikasi intrapersonal, seorang komunikator tidak dapat menerima feedback dengan segera karena proses pengiriman pesan keduanya berbeda. Dari segi kefektifannya, komunikasi tatap muka lebih efektif daripada komunikasi tatap muka. Hal itu karena dalam berkomunikasi secara tatap muka isi atau kedalaman sebuah pesan dapat tersampaikan dengan jelas dan juga dipertegas dengan komunikasi non verbal dari komunikator yang dapat dilihat langsung. Komunikasi intrapersonal mungkin lebih efisien dan rahasia daripada komunikasi tatap muka, karena adanya faktor kecepatan dan keluasan informasi.

\section{Pengertian Komunikasi Intrapersonal}

Komunikasi intrapersonal adalah penggunaan bahasa atau pikiranyang terjadi di dalam diri komunikator sendiri. Komunikasi intrapersonal merupakan keterlibatan internal secara aktif dari individu dalam pemrosesan simbolik dari pesan-pesan. Seorang individu menjadi pengirim sekaligus penerima pesan, memberikan umpan balik bagi dirinya sendiri dalam proses internal yang berkelanjutan. Komunikasi intrapersonal dapat menjadi pemicu bentuk 
komunikasi yang lainnya. Pengetahuan mengenai diri pribadi melalui prosesproses psikologis seperti persepsi dan kesadaran (awareness) terjadi saat berlangsungnya komunikasi intrapribadi oleh komunikator. Untuk memahami apa yang terjadi ketika orang saling berkomunikasi, maka seseorang perlu untuk mengenal diri mereka sendiri dan orang lain. Karena pemahaman ini diperoleh melalui proses persepsi. Maka pada dasarnya letak persepsi adalah pada orang yang mempersepsikan, bukan pada suatu ungkapan ataupun obyek.

\section{Segmentasi Komunikasi Intrapersonal}

Aktivitas dari komunikasi intrapersonal yang dilakukan sehari-hari dalam upaya memahami diri personal diantaranya adalah; berdo'a, bersyukur, instrospeksi diri dengan meninjau perbuatan kita dan reaksi hati nurani kita, mendayagunakan kehendak bebas, dan berimajinasi secara kreatif.Pemahaman diri pribadi ini berkembang sejalan dengan perubahan perubahan yang terjadi dalam hidup kita. Kita tidak terlahir dengan pemahaman akan siapa diri kita, tetapi prilaku kita selama ini memainkan peranan penting bagaimana kita membangun pemahaman diri pribadi ini.

Kesadaran pribadi (self awareness) memiliki beberapa elemen yang mengacu pada identitas spesifik dari individu (Fisher 1987: 134). Elemen dari kesadaran diri adalah konsep diri, proses menghargai diri sendiri (self esteem), dan identitas diri kita yang berbeda beda (multiple selves).

Namun, pada tahun 1992, sebuah bab dalam Komunikasi Yearbook \#15, berpendapat bahwa "komunikasi intrapersonal" adalah sebuah konsep yang cacat. Bab ini pertama diperinci berbagai definisi. Komunikasi intrapersonal, tampak, muncul dari serangkaian kejanggalan logis dan linguistik. Pengertian tentang 'communicaton intrapersonal' itu sendiri adalah ambigu: banyak definisi tampak melingkar karena mereka meminjam, menerapkan dan dengan demikian mendistorsi fitur konseptual (misalnya, pengirim, penerima, pesan, dialog) ditarik dari komunikasi antar-orang normal, tidak diketahui entitas atau orang bagian yang diduga melakukan 'intrapersonal' tukar, dalam banyak kasus, sebuah bahasa yang sangat pribadi yang mengemukakan, setelah analisis, ternyata benar-benar dapat diakses dan akhirnya tidak dapat dipertahankan. Secara umum, komunikasi intrapersonal tampaknya timbul dari kecenderungan untuk menafsirkan proses mental batin yang mendahului dan menyertai perilaku komunikatif kita seolah-olah mereka juga jenis lain proses komunikasi. Titik keseluruhan adalah bahwa rekonstruksi proses mental batin kita dalam bahasa dan idiom percakapan sehari-hari masyarakat sangat dipertanyakan, lemah di terbaik.

\section{Terori-teori Komunikasi Intrapersonal}

a. Psikologi Sosial

Psikologi social adalah suatu studi ilmiah tentang pengalaman dan tingkah laku individu-individu dalma hubungan denagn situasi social. Latar belakang timbulnya psikologisosial berasal dari beberapa pandapat, misalnya Gabriel 
Tarde mengatakan, pokok-pokok teori psikologisosial berpangkal pada proses imitasi sebagai dasar dari pada interaksi social antar manusia.

Gustave Le Bon berpendapat bahwa pada manusia terdapat dua macam jiwa yaitu jiwa individu dan jiwamassa yang masing-masing berlainan sifatnya. Sigmund Freud berbeda dengan Le Bon, ia berpendapat bahwa jiwa massa itu sebenarnya sudah terdapat dan tercakup oleh jiwa individu, hanya saja tidakdisadari oleh manusia itu sendiri karena memang dalam keadaan terpendam.

Pada tahun 1950 dan 1960 psikologi social tumbuh secara aktif dan program gelar dalam psikologi dimulai disebagian besar universitas. Dasar mempelajari psikologi social bedasarkan potensi-potensi manusia dimana potensi ini mengalami proses perkembangan setelah individu itu hidup dalam lingkungan. Potensi-potensi itu antara lain:

1) Kemampuan menggunakan bahasa.

2) Adanya sikap etik.

3) Hidup dalam 3 dimensi.

b. Teori Pengolahan Informasi (Information Processing Theory)

Teori ini menyatakan bahwa informasi mula-mula disimpan pada sensory storage (gudang inderawi), kemudian masuk short-term-memory (STM) lalu dilupakan atau dikoding untuk dimasukkan ke dalam long-term-memory (LTM). Otak manusia dianalogikan dengan komputer.

Terdapat dua macam memori: memori ikonis untuk materi yang kita peroleh secara visual, dan memori ekosis untuk materi yang masuk secara auditif (melalui pendengaran). Penyimpanan disini berlangsung cepat, hanya berlangsung sepersepuluh sampai seperempat detik.

Supaya dapat diingat, informasi harus dapat disandi (encoded) dan masuk pada STM. STM hanya mampu mengingat tujuh (plus atau minus dua) bit informasi. Jumlah bit informasi disebut rentangan memori (memori span). Untuk meningkatkan kemampuan STM, para psikolog menganjurkan kita untuk mengelompokkan informasi; kelompoknya disebut chunk.

Bila informasi dapat dipertahankan pada STM, ia akan masuk pada LTM. Inilah yang umumnya disebut sebagai ingatan. LTM meliputi periode penyimpanan informasi sejak semenit sampai seumur hidup. Kita dapat memasukkan informasi dari STM ke LTM dengan chunking, rehearsals, clustering, atau method of loci.

c. Teori Aus

Menurut teori ini, memori hilang atau memudar karena waktu. Seperti otot, memori kita baru kuat bila dilatih terus menerus. Namun menurut Hunt, makin sering mengingat, makin jelek kemampuan mengingat. Dimana tidak selamanya waktu dapat mengauskan memori.

Adapun dalil tentang Komunikasi Intrapersonal sebagai berikut:

1) Zikir: surah al-Baqarah (2) ayat 152, surah ar-Rad (13) ayat 28-29, surah Thaha (20) ayat 130. 
2) Berdo'a: surah al-Baqarah (2) ayat 186, surah al-Mu'min (40) ayat $60 .{ }^{1}$

\section{Pengertian Kesehatan Mental}

Dari data-data kepustakaan menunjukkan bahwa timbulnya gerakan kesehatan mental (mental hygiene) ini disarankan oleh seorang bekas penderita gangguan mental yang bernama Clifford Whittingham Beers (1876-1943). Dalam bukunya, Beers mengisahkan pengalamannya, betapa kejam dan kerasnya cara penyembuhan atau pengobatan di dalam rumah sakit jiwa (asylum) sering dia didera dengan pukulan-pukulan dan hinaan-hinaan yang menyakitkan. Selanjutnya, Beers menuturkan pengalamannya selama dalam perawatan menunjukkan pentingnya "penerimaan disertai dengan pengertian" (acceptance and understanding) dari orang kepada orang lain.sikap penerimaan dan pengertian inilah yang telah menyembuhkannya lebih banyak di samping usaha-usaha lainnya.

Akibat dari tulisan Beers inilah yang kemudian mendorong orang untuk menolong orang lain yang menderita gangguan mental, kemudian setelah diketahui hasilnya baik sekali, maka usaha mental hygiene ini meluaskan diri kepada siapa saja yang memerlukan pertolongan. Karena usaha ini meliputi seluruh pribadi seseorang, maka dasar-dasar untuk mempelajari usaha ini juga memerlukan pengetahuan lain yang menyangkut keadaan manusia. Untuk mempelajari kesehatan mental, dasar-dasar pengetahuan yang diperlukan adalah ilmu jiwa umum dan khusus, sosiologi, biologi, ilmu kesehatan, teori kepribadian, dan cara-cara penyelidikannya.

Menurut Prof. Dr. Abdul Azis El-Quussy (1977), kesehatan mental adalah keserasian yang sempurna atau integrasi antara fungsi-fungsi jiwa yang bermacam-macam, disertai kemampuan untuk menghindari kegoncangankegoncangan jiwa yang ringan, yang biasa terjadi pada orang di samping secara positif, dapat merasakan kebahagiaan dan kemampuan.

Lain halnya pendapat dari Zakiah Daradjat (1983), ia menuturkan kesehatan mental adalah pengetahuan dan perbuatan yang bertujuan untuk mengembangkan dan memanfaatkan segala potensi, bakat, dan pembawaan yang ada semaksimal mungkin, sehingga membawa kebahagiaan diri dan orang lain, serta terhindar dari gangguan-gangguan penyakit jiwa.

Sedangkan menurut Harlord W. Bernard (1970), kesehatan mental didefinisikan sebagai penyesuaian individu terhadap dirinya sendiri dan lingkungan sekitarnya dengan seefektif mungkin, senang hati, kegembiraan, dan tingkah laku sosial yang baik, serta kemampuan untuk menghadapi dan menerima kenyataan hidup.

Dari beberapa definisi tentang kesehatan mental seperti tersebut di atas dapat di ambil simpulan:

\footnotetext{
${ }^{1}$ Saiful Akhyar Lubis, 2015. Konseling Islami dalam Komunitas Pesantren. Bandung: Citapustaka Media Perintis
} 
a. Kesehatan mental dipandang sebagai sesuatu kondisi atau keadaan mental yang sehat.

b. Kesehatan mental dipandang sebagai pengetahuan, perbuatan, bahkan seni untuk mencapai kondisi mental yang sehat.

c. Kesehatan mental dipandang sebagai aktifitas penyesuaian individu untuk memperoleh kondisi mental yang sehat.

\section{Sejarah Kesehatan Mental}

Kesehatan mental juga memiliki batasan-batasan norma yang harus ditaati, sebab dengan norma yang jelas, bisa diketahui orang-orang yang bertingkah laku normal atau tidak normal, sehat atau tidak sehat mentalnya. Kejelasan batas antara mereka yang normal dan tidak normal ini penting sekali terutama dalam kaitannya dengan proses pendidikan, bimbingan dan penyuluhan serta psikoterapi.

Secara umum istilah "normal" adalah biasa, menurut ukuran (Osmin Raliby, 1982:37 dalam Munif Prasetyo dan Anwar Sutoyo, 2000: 4); sedang dalam kesehatan mental kata "normal" berarti "sehat". Jadi, tingkah laku normal adalah tingkah laku yang sehat, dan tingkah laku yang tidak normal adalah tingkah laku yang sakit (Hasan Langgulung, 1986:37 dalam Munif Prasetyo dan Anwar Sutoyo, 2000:4). Normal atau sehat adalah tanda bagi adanya kesehatan psikis secara umum, sedangkan tingkah laku normal atau sehat adalah tanda atau gejala yang menunjukkan adanya kesehatan mental itu pada seseorang.

Menurut para ahli (Hasan Langgung, 1986:38 dalam Munif Prasetyo dan Anwar Sutoyo, 2000:4), norma-norma kesehatan mental adalah:

a. Metode Statistik

Metode ini digunakan berdasarkan kenyataan, bahwa jika kita mengukur salah satu aspek jasmani, intelektual, atau emosi; kemudian kita lukiskan pertalian antara angka-angka itu, akan kita dapati bahwa angka-angka itu cenderung pada grafik tertentu, dimana kebanyakan angka-angka dari hasil pengukuran itu berada di tengah-tengah, sedang angka-angka yang berada di bawah rata-rata mengelompok pada ujung sebelah kiri dan angka-angka yang rata-rata mengelompok pada ujung sebelah kanan.

Jadi, orang-orang yang memperoleh angka pertengahan adalah orangorang yang normal, yang memperoleh angka di bawah rata-rata disebut "dikelompokkan sebagai di bawah normal", dan mereka yang meperoleh angka di atasa rata-rata tersebut "di atas normal". Pengukuran psikis atau mental tidak bisa dilakukan secara langsung pada ospek yang sedang diukur, tidak mengenal satuan ukuran, bersifat relatif, bersifat dekriptif, dan tidak mungkin menghindari salah ukur. (Martensi KDJ, 1988 dalam Munif Prasetyo dan Anwar Sutoyo, 2000:7)

Metode statistik lebih menjamin obyektifitas dalam membedakan mereka yang normal dan tidak normal, karena dalam analisisnya digunakan simbolsimbol angka dan rumus-rumus yang bersifat eksak, dan bisa dilakukan oleh siapapun dengan hasil yag sama. Hasil pengukuran yang berupa angka-angka 
itu diperoleh dari pengukuran ysng bersifat tidak langsung terhadap aspek yang diukur, belum/tidak adanya satuan ukuran yang pasti, dan hasil pengukurannyapun bersifat diskriptif yang tidak menunjukkan sifat mutlak tetapi lebih condong pada relatif.

b. Norma-norma Sosial

Tingkah laku normal adalah tingkah laku yang sesuai dengan normanorma sosial dalam masyarakat tertentu, sedang tingkah laku tidak normal adalah tingkah laku yang tidak sesuai dengan norma masyarakat, oleh Sheriff pada tahun 1936. (Hasan Langgulung 1986:42 dalam Munif Prasetyo dan Anwar Sutoyo, 2000: 8).

Norma sosial adalah segala pola tingkah laku, sikap sosial, nilai-nilai dan lain-lain yang disetujui dan diterima oleh kumpulan. Menurut B. Simanjuntak (1983:16 dalam Munif Prasetyo dan Anwar Sutoyo, 2000:9), yang termasuk ke daam norma ini adalah hukum, agama, kesusilaan, dan adat istiadat, kaidahkaidah sosial ini adalah petunjuk hidup yang menentukan sikap manusia dalam pergaulannya dengan manusia lain, petunjuk hidup yang memaksa ini disebut kaidah sosial (B. Simanjuntak, 1983:16 dalam Munif Prasetyo dan Anwar Sutoyo, 2000:9).

Apa yang dianggap normal pada lingkungan masyarakat tertentu belum tentu dianggap normal pada lingkungan masyarakat yang lain, dan berlakunya norma masyarakat ini juga terbatas pada waktu tertentu selama diakui oleh masyarakat tertentu dan masyarakat itupun masih mendukungnya, bila masyarakat itu sudah tidak lagi mendukungnya, maka secara berangsur-angsur hilanglah norma itu.

Menurut norma sosial, oarang yang mempunyai kesehatan mental yang wajar adalah orang yang sanggup berpegang pada apa yang orang lain atau orang yang memegang peranan sosial tertentu dengan tepat dan baik.

c. Tingkah Laku Pengukuran

Untuk menentukan tingkah laku normal bukan terletak pada penerimaan atau penolakan terhadap tingkah laku itu, tetapi terletak pada kesanggupan tingkah laku ini untuk menumbuhkan dan mewujudkan potensi-potensi seseorang dan kumpulan, atau yang disebut tingkah laku pengakuran (conformity). Jadi, dalam menentukan batas antara sehat mental dengan tidak sehat mental; ada yang berpijak pada norma statistik, norma sosial, dan tingkah laku pengakuran.

\section{Prinsip-prinsip Kesehatan Mental}

Prinsip-prinsip kesehatan mental dalam Islam adalah Al-Qur'an dan hadits yang memandang bahwa keberhasilan seseorang dalam semua sisi kehidupaannya tidak lepas dari peran dan campur tangan Allah SWT sebagai Dzat yang mengatur segala urusan dilangit dan dibumi. Demikian juga dalam keberhasilan prestasi akademik yang diraih peserta didik tentu juga Allah SWT yang mengatur. Untuk itu dalam prakteknya, kesehatan menatl bukan terbatas 
pada fisik, akan tetapi menekankan pada usaha rohani. Melaui penanaman nilainilai agama diharapkan dapat melahirkan manusia yang tidak hanya cerdas, tapi juga bertakwa kepada Allah SWT serta memiliki akhlak yang mulia. Generasi seperti itu tentu lebik baik dari pada generasi yang sekedar cerdas akademik. Untuk itu penanaman nilai-nilai agama dalam kesehatan mental memiliki keterlibatan signifikan dalam membentuk pribadi-pribadi yang sholeh, cerdas dan berakhlakul karimah. Pribadi-pribadi yang semacam inilah yang diharapkan mampu memimpin dan memajukan bangsa.

Dengan kata lain, dalam khazanah dunia pendidikan Islam, konsep pendidikan menekankan bimbingan konseling yang menjaga keseimbangan antara aspek jasmani dan rohani dengan tujuan akhir tidak hanya bermuara pada aspek kognitif peserta didik, tapi juga berbagai aspek positif yang melingkupinya. Dengan demikian, misi pendidikan yang ideal tidak hanya terletak pada upaya mencerdaskan peserta didik, tapi yang jauh lebih penting adalah upaya-upaya yang bermuara pada pembentukan moral dengan menempatkan belajar sebagai aktivitas ibadah yang diharapkan mengatar peserta didik memperoleh kebahagiaan duniawi dan ukhrawi. Karenanya belajar harus diniatkan untuk mencari ridha Allah, kebahagian akhirat, mengembangkan dan melestarikan Islam, mensyukuri nikmat akal, serta menghilangkan kebodohan. ${ }^{2}$

Sehubungan dengan hal tersebut diatas, dalam pelaksanaan bimbingan konseling Islami, prinsip-prinsip kesehatan mental mestinya ditinjau sebagai berikut:

a. prinsip landasan dan dasar hanya beriman kepada Allah SWT;

b. prinsip kepercayaan beriman kepada malaikat;

c. prinsip kepemimpinan beriman kepada nabi dan rasulnya;

d. prinsip pembelajaran beriman kepada Al-Qur'an Al karim;

e. prinsip masa depan beriman kepada hari kemudian; dan

f. prinsip keteraturan beriman kepada ketentuan Allah.

Dengan menjalankan bimbingan kesehatan mental yang didasarkan pada prinsip diatas yang tidak lain dengan rukun iman yang yang dikenal dalam Islam, maka pelaksanaan bimbingan dan konseling akan mengarahkan peserta didik kearah kebenaran.

Prinsip dan langkah tersebut di atas penting sebagai bimbingan kesehatan mental, karena diharapkan akan mengahsilkan manusia yang memiliki kecerdasan emosi dan spiritual yang sangat tinggi dengan pribadi-pribadi yang sholeh, cerdas, berakhlakul kharimah serta membuat mereka menjadi manusia yang beriman dan bertakwa kepada Tuhan yang Maha Esa, berakhlak mulia, sehat, berilmu, cakap, kreatif, mandiri dan menjadi warga negara yang

${ }^{2}$ Lubis Syukur, 2009. Bimbingan Konseling dalam Persfektif Islam. Bandung: Cipta Pustaka Media Perintis 
demokratis serta bertanggung jawab sesuai dengan yang diamanatkan oleh sistem pendidikan nasional.

Berkenaan dengan dimensi spiritual dalam konseling Islami, Allah ditempatkan pada posisi Konselor Yang Maha Agung, satu-satunya tempat manusia menyerahkan diri dan permasalahannya, sebagai sumber penyelesaian masalah, sumber kekuatan dan pertolongan, sumber kesembuhan. Sehingga Agama menjadi tempat yang sangat cocok untuk manusia dijadikan tempat kesehatan mental. Pengertian ini jelas terungkap isyaratnya dalam surah alBaqarah (2) ayat 112, 156, 255, 284, Surah ali-Imran (3) ayat 159-160, Surah atTalaq (65) ayat 3-4, sebagai berikut:

Artinya: "Allah, tidak ada tuhan selain Dia.Yang Maha Hidup, Yang terus menerus Mengurus (makhluk-Nya), tidak mengantuk dan tidak tidur. MilikNya apa yang ada di langit dan apa yang ada di bumi. Tidak ada yang dapat memberi syafaat di sisi-Nya tanpa izin-Nya. Dia Mengetahui apa yang di hadapan mereka dan apa yang di belakang mereka, dan mereka tidak mengetahui sesuatu apa pun tentang ilmu-Nya melainkan apa yang Dia Kehendaki. Kursi-Nya meliputi langit dan bumi. Dan Dia tidak merasa berat Memelihara keduanya, dan Dia Maha Tinggi, Maha Besar." (TQS. Al-Baqarah: 255).

Inti makna surah al-Baqarah ayat 255 di atas adalah Allah menegaskan akan kekuasaannya terhadap seluruh alam. Ia secara terus-menerus mengurus makhluknya. Hanya dialah penguasa sebagai pemberi pertolongan, dan hanya dia yang berhak disembah.

Artinya: Maka berkat rahmat Allah engkau (Muhammad) berlaku lemah lembut terhadap mereka. Sekiranya engkau bersikap keras dan berhati kasar, tentulah mereka menjauhkan diri dari sekitarmu. Karena itu maafkanlah mereka dan mohonkanlah ampunan untuk mereka, dan bermusyawarahlah dengan mereka dalam urusan itu. Kemudian, apabila engkau telah membulatkan tekad, maka bertawakallah kepada Allah. Sungguh, Allah Mencintai orang yang bertawakal. Jika Allah Menolong kamu, maka tidak ada yang dapat mengalahkanmu, tetapi jika Allah Membiarkan kamu (tidak memberi pertolongan), maka siapa yang dapat menolongmu setelah itu? Karena itu, hendaklah kepada Allah saja orangorang Mukmin bertawakal. (TQS. Ali-Imran: 159-160).

Inti makna dari surah Ali-Imran ayat 159-160 adalah: Allah menegaskan bahwa dia adalah satu-satunya tempat bertawakal (berserah diri) bagi orangorang mukmin, dan dia sangan menyenangi sikap tawakal.

Berkenaan dengan dimensi material dalam kesehatan mental, klien/konseli dipandang sebagai manusia dengan keharusan memahami masalah empirik yang dihadapinya serta sekaligus menyadari hakikat jati diri dan tanggungjawabnya 
untuk menyelesaikan masalah tersebut. Hal ini dengan jelas tertera dalam surah al-Baqarah ayat 30, dan surah al-Ahzab ayat 22 adalah: Allah menjelaskan bahwa manusia diciptakannya menjadi khalifah (kuasa atau wakilnya) dibumi yang bertugas sebagai pengelola dan penata kehidupan (dalam arti luas) demi kesejahteraan diri berikut dunianya sesuai dengan kehendak Allah (mengemban misi khalifah).

Manusia dan segala kompleksitas permasalahannya sebagai objek konseling tertulis dan terdapat di dalam al-Qur'an secara jelas, sebagai berikut:

a. Dalam konseling islami, permasalahan yang dihadapi manusia pada kehidupannya adalah wujud kebencian Allah kepada hambanya. Isyarat ini termaktub dalam surah al-Baqarah ayat 155, dan surah at-Tagabun ayat 15.

b. Dalam posisinya sebagai klien/konseli, konseling islami memandang manusia sebagai individu yang memiliki potensi untuk hidup sehat secara mental. Untuk itu, ia dibekali/dianugerahkan oleh Allah berbagai potensi yang baik agar ia mampu menghadapi dan menyelesaikan masalah dalam kehidupannya, sehingga diyakini ia akan dapat dibantu untuk berhasil menyelesaikan masalah dimaksud, apalagi memang kerumitan masalah yang dihadapinya masih sesuai dengan taraf kemampuannya (masih dalam batas kemampuannya). Anugerah Allah berupa potensi yang baik kepada manusia termaktub dalam surah al-baqarah (2) ayat 31, surah an-nisa (4) ayat 113, surah al-Isra' (17) ayat 70, surah as-Sajdah (32) ayat 7-9. Surah al-Balad (90) ayat 10, surah asy-Syams (92) ayat 8 , surah at-Tin (95) ayat 4.

c. Penjelasan tentang kerumitan masalah masih sesuai dengan taraf kemampuan (masih dalam batas kemampuan) manusia termaktub pula dalam surah al-Baqarah (2) ayat 233 dan 286, surah an-Nisa (4) ayat 84, surah al-an'am (6) ayat 152, surah al-A'raf (7) ayat 42, surah al-Mu'minun (23) ayat 62 , surah sad (38) ayat 86 , surah at-Talaq (85) ayat 7 . Inti makna surah al-Baqarah (2) ayat 233 dan 286, surah al-an'am (6) ayat 152, surah al-a' raf (7) ayat 42 , surah al-mu'minun (23) ayat 62 , surah at-talaq (65) ayat 7.

d. Atas dasar poteni dan kemampuan yang dimiliki manusia, maka dalam proses kesehatan mental, klien/konseli didorong untuk melakukan self counseling. Dialah orang paling dituntut untuk melakukan upaya melakukan kreatif mandiri untuk itu, ia harus mengembangkan upaya ikhtiarnya secar mandiri, karena hasilnya akan sangan tergantung pada kemampuan ikhtiarnya tersebut. Isyarat tentang hal ini termaktub dalam surah ar-Ra'd (13) ayat 11 dan surah an-najm (53) ayat 39-40.

e. Upaya kesehatan mental menggiring klien/konseli untuk memperoleh ketenangan hati. Secara spiritual memperoleh ketenangan hati adalah kembali kepada sumbernya, yaitu Allah. Dalam hal ini, iman dan amal akan menyempurkanan ketenangan hati. Untuk itu, ia harus melaksanakan ibadah dengan tulus dan khusyuk', baik ibadah wajib (shalat,zakat, puasa, haji) 
maupun ibadah sunnah (zikir, membaca al-Qur'an, berdoa). Ayat-ayat alQur'an yang menjelaskan hal-hal tersebut adalah sebagai berikut:

1) Shalat: surah al-Baqarah (2) ayat 45 dan 153, surah Hud (11) ayat 114, surah al-isra' (17) ayat 78-79.

2) Zakat: surah al-Baqarah (2) ayat 110, surah at-Taubah (9) ayat 103, surah an-Nur (24) ayat 56, surah al-Bayyinah (98) ayat 5.

3) Puasa: surah al-Baqarah (2) ayat 183-184.

4) Ibadah haji: surah al-Baqarah (2) ayat 196-200, surah ali-Imran (3) ayat 97, surah al-Hajj (22) ayat 26-32.

5) Berdo'a: surah al-Baqarah (2) ayat 186, surah al-Mu'min (40) ayat $60 .^{3}$

\section{Ruang Lingkup Kesehatan Mental}

Kesehatan mental memiliki ruang kajian yang sangat luas. Ruang lingkup kesehatan mental antara lain sebagai berikut:

a. Mental Hygiene dalam Keluarga

Amatlah penting bagi pasangan suami istri dalam mengelola keluarga untuk menciptakan keluarga yang sakinah mawaddah warahmah untuk memahami konsep-konsep atau prinsip-pronsip kesehatan mental hygiene ini, yang berfungsi untuk mengembangkan mental yang sehat atau mencegah terjadinya mental yang sakit pada anggota keluarga.

b. Mental Hygiene di Sekolah

Gagasan ini didasarkan pada asumsi bahwa "perkembangan kesehatan mental peserta didik dipengaruhi oleh iklim sosio-emosional di sekolah." Pemahaman pimpinan sekolah dan guru-guru (terutama guru BK atau konselor) tentang mental hygiene sangatlah penting. Pimpinan dan para guru secara sinerji dapat menciptakan iklim kehidupan sekolah (fisik, emosional, sosial, maupun moral spiritual) untuk perkembangan kesehatan mental para siswa.

Di samping itu mereka dapat memantau gejala gangguan mental para siswa sedini mungkin. Mereka dapat memahami masalah mental yang dapat diatasi sendiri dan mana Sekolah Menangah Pertama (SMP) dan Sekolah Menengah Atas (SMA) perlu memahami kesehatan mental siswanya yang berada pada masa transisi, karena tidak sedikit siswanya yang mengalami kesulitan mengembangkan mentalnya karena terhambat oleh masalahmasalahnya, seperti penyesuaian diri, konflik dengan orang tua atau teman, masalah pribadi, masalah akademis yang semuanya dapat menjadi sumber stres.

c. Mental Hygiene di tempat Kerja

Lingkungan kerja memainkan peranan penting dalam kehidupan manusia. Lingkungan kerja tidak hanya menjadi tempat mencari nafkah, ajang persaingan bisnis, dan peningkatan kesejahteraan hidup, tetapi juga menjadi

\footnotetext{
${ }^{3}$ Saiful Akhyar Lubis, 2015. Konseling Islami dalam Komunitas Pesantren. Bandung: Citapustaka Media Perintis
} 
sumber stres yang memberikan dampak negatif terhadap kesehatan mental bagi semua orang yang berinteraksi di tempat tersebut.

Banyak masalah yang mengakibatkan gangguan mental di tempat kerja yang diakibatkan oleh stres, apabila masalah-masalah tersebut menimpa suatu lembaga atau perusahaan, maka akan terjadi stagnasi produktivitas kerjadi di kalangan pimpinan atau karyawan. Jika hal ini terjadi, amaka tinggal menunggu kebangkrutan lembaga atau perusahaan tersebut.

Berdasarkan hal itu, bagi para pimpinan lembaga pemerintah/ swasta yang menginginkan tercapainya keberhasilan. Sangatlah penting untuk memperhatikan mental hygiene ini, agar mereka dapat mengembangkan kiatkiat untuk mencegah terjadinya maslaah gangguan emosional, datu memperkecil sumber-sumber terjadinya stres.

d. Mental Hygiene dalam Kehidupan Politik

Tidak sedikit orang yang bergelut dalam bidang politik yang mengidap gangguan mental, seperti: pemalsuan ijazah, money politic, KKN (Kolusi, Korupsi, Nepotisme), khianat kepada rakyat dan stres yang menimbulkan perilaku agresif karena gagal menjadi calon legislatif, dll.

e. Mental Hygiene di Bidang Hukum

Seorang hakim perlu memiliki pengetahuan tentang mental hygiene, agar dapat mendeteksi tingkat kesehatan mental terdakwa atau para saksi saat proses pengadilan berlangsung, dimana sangat berpengaruh terhadap pengambilan keputusan hukum.

f. Mental Hygiene dalam Kehidupan Beragama

Pendekatan agama dalam penyembuhan gangguan psikologis merupakan bentuk yang paling tua. Telah beberapa abad lamanya, para nabi atau para penyebar agama melakukan terapeutik.

Semakin kompleks kehidupan, semakin penting penerapan mental hygiene yang bersumber dari agama dalam rangka mengembangkan atau mengatasi kesehatan mental manusia. Ada kecenderungan orang-orang di zaman modern ini semakin rindu atau haus akan nilai-nilai agama, seperti ceramah atau tausiyah. Mereka merindukan hal itu dalam upaya mengembangkan wawasan keagamaannya, atau mengatasi masalah-masalah kehidupan yang sulit diatasinya tanpa nasihat keagamaan tersebut.

\section{PENUTUP}

\section{A. Simpulan}

Berdasarkan analisis, dapat disimpulkan bahwa Peran Komunikasi Interpersonal terhadap Kesehatan Mental Seseorang berdampak. Karena dalam prosesnya, Komunikasi Interpersonal bersiifat dialogis. Maksudnya, ditunjukan melalui komunikasi lisan dalam percakapan yang menampilkan arus balik yang langsung. Jadi komunikator mengetahui tanggapan komunikan pada saat itu juga, komunikator mengetahui dengan pasti apakah pesan-pesan yang dia kirimkan itu diterima atau ditolak, berdampak positif atau negatif. Jika tidak 
diterima maka komunikator akan memberi kesempatan seluas-luasnya kepada kommunikasi untuk bertanya. Jadi, komunikasi interpersonal berpengaruh terhadap kesehatan mental seseorang, karena pada prosesnya komunikasi interpersonal bersifat dialogis, yang mana komunikan akan berperan untuk menyeimbangi peran komunikator, agar tercipta pola komunikasi yang baik.

\section{B. Saran}

Berdasarkan penelitian yang telah dilakukan, penulis memberikan saran kepada beberapa pihak yang fokus menangani bimbingan dan konseling Islam serta Ilmu Tafsir. Saran pertama, ditujukan kepada individu masyarakat. Tiap individu harus memelihara diri dari hal-hal yang mengakibatkan terganggunya mental, sehingga mengakibatkan mental tidak sehat. Kedua, ditujukan pada kedua orang tua (keluarga). Keluarga juga berperan penting menumbuhkan kesadaran individu masyarakat. Karena keluarga menjadi pondasi awal masayarakat dalam menilai kehidupan di luar rumah. Ketiga, ditujukan pada masyarakat. Sebab, masyarakat mempunyai peran yang besar dan strategis untuk perilaku masyarakat sekitar. Masyarakat pula yang menjadi lingkungan sekitar menjalani aktivitas sosialnya, sehingga aktivitas sosial masyarakat dapat terkontrol baik berkat tanggung jawab bersama.

\section{DAFTAR PUSTAKA}

Al-Qur'anul karim. 2007 . Syaamil Al-Qur'an Terjemah Tafsir Perkata. Bandung: Sygma, Syaamil Al-Qur'an 
